\title{
POTENSI PENINGKATAN AKSES PASAR PRODUK INDONESIA KE PEREKONOMIAN APEC UNTUK MENGANTISIPASI REALISASI FTAAP
}

\section{Potential Improvement of the Indonesian Products Market Access to APEC Economies to Anticipate the Possibility of FTAAP Realization}

\author{
Rino Adi Nugroho, Kumara Jati \\ Pusat Pengkajian Kerjasama Perdagangan Internasional, Kementerian Perdagangan-RI, \\ JI.M.I. Ridwan Rais No.5 Jakarta, 10110, Indonesia \\ Email: ran.kemendag@gmail.com
}

Naskah diterima: 10/02/2018; Naskah direvisi: 21/03/2018; Disetujui diterbitkan: 11/12/2018

Dipublikasikan online: 31/12/2018

\begin{abstract}
Abstrak
Tulisan ini mengkaji potensi peningkatan akses pasar produk Indonesia ke kawasan AsiaPacific Economic Cooperation (APEC) untuk mengantisipasi realisasi Free Trade Area of The Asia-Pacific (FTAAP). Penelitian ini menggunakan Export Product Dynamic (EPD), IntraIndustry Trade (IIT), dan analisis Inter-Regional Input-Output (IRIO). Hasil analisis EPD dengan menggunakan klasifikasi 21 sektor diperoleh 15 sektor ekspor Indonesia ke pasar Asia-Pasifik berada pada posisi retreat dan enam sektor lainnya berada pada posisi falling star. Berdasarkan hasil IIT diperoleh lima sektor ekspor Indonesia yang memiliki integrasi dalam kategori integrasi sangat kuat yaitu sektor hasil panen dan hewan, industri pengolahan makanan dan tembakau, industri farmasi, industri karet dan plastik, serta industri perakitan komputer. Sementara itu berdasarkan analisis Inter-Regional Input-Output (IRIO) terhadap 10 ekonomi Asia-Pasifik terlihat bahwa proporsi perdagangan bilateral terhadap total ekspor terbesar yaitu Indonesia terhadap Republik Rakyat Tiongkok (RRT) dan Jepang dengan persentase masing-masing sebesar 1,22\% diikuti oleh Korea Selatan dan Jepang masingmasing sebesar 0,4\% dan 0,32\%. Ekspor Indonesia ke Australia, RRT, Jepang, Korea Selatan, Meksiko, Rusia dan Taiwan didominasi oleh barang antara dan ekspor Indonesia ke Amerika Serikat dan Kanada didominasi oleh barang konsumsi langsung. Untuk memperoleh nilai tambah, Indonesia perlu meningkatkan daya saing melalui transfer teknologi dan akses pasar yang fokus pada permintaan akhir.
\end{abstract}

Kata Kunci: Export Product Dynamic (EPD), Intra-Industry Trade (IIT), Inter-Regional InputOutput (IRIO), Asia-Pacific Economic Cooperation (APEC), Free Trade Area of The Asia-Pacific (FTAAP)

Abstract
This paper examines the potential improvement of market access of Indonesian products to the Asia-Pacific Economic Cooperation (APEC) region to anticipate the possibility of the Free Trade Area of The Asia-Pacific (FTAAP) realization. The methods used in this research are Export Product Dynamic (EPD), Intra-Industry Trade (IIT), and Inter-Regional Input-Output (IRIO) analysis. Based on the analysis of EPD using 21 sectors classification, it was obtained 15 export sectors of Indonesia to Asia-Pacific market are in retreat position and other six sectors are in falling star position. While using the IIT method, there are five Indonesian export sectors that have very strong integration, namely and animal sector, food and tobacco processing industry, pharmaceutical industry, rubber and plastics industry, and computer docking industry. In addition, by using IRIO analysis on 10 Asia-Pacific economies, it showed that the largest share of Indonesia bilateral trade was to China and Japan at about $1.22 \%$ respectively. This was followed by South Korea and Taiwan with percentage of $0.4 \%$ and $0.32 \%$. The exports of Indonesia to Australia, China, Japan, South Korea, Mexico, Russia and Taiwan were dominated by the intermediate goods, while to the United States and Canada 
are dominated by final goods. Therefore, to obtain added value, Indonesia's has to improve competitiveness with technology transfer and market access increase which focuses on the final demand.

Keywords: Export Product Dynamic (EPD), Intra-Industry Trade (IIT), Inter-Regional InputOutput (IRIO), Asia-Pacific Economic Cooperation (APEC), Free Trade Area of The Asia-Pacific (FTAAP)

JEL Classification: D57, F13, F15, F41

\section{PENDAHULUAN}

Sejak tahun 1990-an, kerja sama perdagangan internasional dan ekonomi sangat pesat berkembang. Namun, Indonesia merupakan negara yang kurang agresif dalam ikut menjalin kerja sama perdagangan. Ini terlihat dari data tahun 2015 bahwa Indonesia hanya tergabung dalam delapan (8) perjanjian perdagangan internasional yang terdiri dari: dua (2) perjanjian bilateral dan enam (6) perjanjian regional. Kerja sama itu sebagai berikut: ASEAN Free Trade Area (AFTA); ASEAN-Australia dan Selandia Baru FTA; ASEAN-China FTA; ASEAN-India FTA; ASEAN-Jepang FTA; dan ASEANKorea FTA. Dua perjanjian bilateral yang ditandatangani Indonesia adalah Indonesia-Jepang Economic Partnership Agreement (IJEPA) dan Indonesia-Pakistan Preferential Trade Agreement (IPPTA).

Indonesia masih tertinggal dalam hal jumlah perjanjian kerja sama perdagangan internasional jika dibandingkan negara lain di ASEAN.
Singapura memiliki 13 perjanjian perdagangan bilateral, Malaysia memiliki tujuh perjanjian perdagangan bilateral, dan Vietnam memiliki lima perjanjian perdagangan bilateral diluar perjanjian dalam kerangka ASEAN. Perjanjian kerja sama perdagangan bilateral ini termasuk perjanjian dengan pasar-pasar utama seperti Uni Eropa, Republik Rakyat Tiongkok (RRT) dan Amerika Serikat.

Pembukaan pasar baru perlu dilakukan Indonesia melalui perjanjian perdagangan internasional supaya mengurangi dampak negatif kehilangan pasar. Negara-negara utama di ASEAN telah mengambil alih ekspor produk utama Indonesia seperti Crude Palm Oil (CPO) dari Malaysia, dan produk alas kaki dan produk kayu dari Vietnam. Indonesia harus lebih agresif dalam membuka pasar baru terutama ke negara-negara yang belum terbuka akses pasarnya seperti negara-negara di kawasan Asia-Pasifik.

Berdasarkan sejarahnya sejak tahun 1989, sudah berdiri APEC (Asia- 
Pacific Economic Cooperation) yang merupakan forum kerja sama antara 21 economies di kawasan AsiaPasifik yang bertujuan mendorong pertumbuhan ekonomi serta meningkatkan kesejahteraan anggotanya (Puska KPI, 2015). Saat ini telah terbentuk 46 bilateral FTA dan 12 perjanjian perdagangan di kawasan Asia-Pasifik yang dalam proses negosiasi (WTO, 2015). Fenomena FTA yang berkembang juga bisa memiliki efek negatif. Ada indikasi bahwa perjanjian perdagangan ini terjadi tumpang tindih dalam skema perdagangan bebas. Efek negatif tumpang tindih (Efek "Noodle Bowl') ini yang terkadang dikhawatirkan karena bisa menghambat dan membingungkan dunia usaha seperti Usaha Kecil dan Menengah (UKM). Maka dari itu, APEC sedang mencari bentuk perjanjian perdagangan di kawasan supaya lebih komprehensif dan detail. Pada pertemuan para pemimpin APEC di Santiago, Chili, pada tahun 2004, disepakati untuk dilakukan kajian kelayakan (feasibility study) pembentukan Free Trade Area of the Asia-Pasific (FTAAP). Tindak lanjut kesepakatan tersebut, APEC telah memprakarsai kajian awal mengenai kemungkinan pembentukan FTAAP.
Pimpinan APEC economies memiliki peran yang kuat dalam mendorong visi FTAAP untuk maju. Pernyataan resmi pertama terkait FTAAP dibuat tahun 2006 oleh pimpinan APEC pada pertemuan di Hahoi Vietnam. Deklarasi berikutnya, oleh pimpinan APEC dilakukan tahun 2007 yang mempromosikan FTAAP yang mencerminkan pentingnya ditempatkan FTAAP dalam rangka memperkuat integrasi ekonomi regional di Asia-Pasifik. Pada deklarasi tahun 2007 ini pimpinan APEC sepakat untuk melihat pilihan dan prospek untuk FTAAP melalui berbagai langkahlangkah praktis dan bertahap.

Tahun 2008, Menteri dan pejabat di APEC economies, akan melakukan langkah-langkah untuk mencapai FTAAP termasuk melakukan penelitian berjudul "Dampak Ekonomi Kemungkinan dari FTAAP”. Pada tahun 2010, para pemimpin APEC melakukan deklarasi untuk membuat persiapan FTAAP serta mengambil langkahlangkah konkret menuju FTAAP. Menurut mereka, FTAAP harus dikejar sebagai FTA yang komprehensif dengan mengembangkan dan membangun usaha daerah yang sedang berlangsung (APEC, 2016). 
Salah satu hasil kajian APEC yang dilakukan oleh Bergsten (2007), berpendapat bahwa FTAAP akan menjadi pilihan kebijakan yang terbaik. FTAAP juga akan menciptakan keuntungan yang positif dari perdagangan bebas tanpa melanggar ketentuan WTO. Selain itu, FTAAP diharapkan dapat mencegah tumpang tindih perdagangan bebas di kawasan Asia-Pasifik dengan mengkonsolidasikan perdagangan sub-regional, dan merevitalisasi APEC.

Indonesia secara ideal harus menjadi bagian dari FTAAP karena perdagangan bebas di kawasan AsiaPasifik baru terwujud di masa yang akan datang. Pemerintah Indonesia harus hati-hati dalam menyetujui perdagangan bebas di kawasan ini supaya kepentingan nasional tidak dirugikan tetapi bisa menjaga kerja sama perdagangan internasional (DJPEN, 2016). Pertimbangan lain bahwa Indonesia sebaiknya bisa mempertimbangkan ikut serta untuk persiapan kemungkinan realisasi FTAAP yaitu dalam rangka peningkatan akses pasar produk Indonesia ke luar negeri khususnya ke perekonomian APEC. Penelitian ini membahas mengenai kerangka kerja sama perdagangan dalam FTAAP dikarenakan kerangka kerja sama ini merupakan upaya APEC dalam mewujudkan integrasi ekonomi regional dan capaian deklarasi Bogor Goals, yaitu penciptaan investasi dan perdagangan yang terbuka. Selain itu, topik kerangka kerja sama FTAAP dipilih dalam penelitian ini karena APEC economies sebagai kandidat kuat anggota FTAAP memiliki kontribusi ekonomi dunia yang cukup besar dengan: market size sebesar 41\%, GDP sebesar $58 \%$ dan perdagangan dunia sebesar $45 \%$.

Berdasarkan penelitian Puska KPI (2015), apabila Indonesia berada di luar FTAAP maka Indonesia bisa kehilangan pangsa ekspor yang besar karena pangsa ekspor Indonesia ke FTAAP sekitar $75 \%$ dari total ekspor Indonesia (dengan asumsi seluruh ekonomi APEC bergabung ke FTAAP). Penelitian ini mengidentifikasi bahwa pemotongan tarif sebesar $50 \%$ akan memiliki dampak kepada peningkatan kesejahteraan mayoritas economies APEC termasuk Indonesia. Peningkatan kesejahteraan juga akan terjadi pada Indonesia jika perjanjian kerja sama FTAAP melakukan liberalisasi penuh. 
Namun penelitian Puska KPI (2015) masih terbatas pada ruang lingkup cost and benefit dari FTAAP saja, serta belum melihat secara detail produk apa yang seharusnya dipromosikan dan memiliki keterkaitan kuat diantara ekonomi APEC. Perbedaan lain dengan penelitian ini yaitu dari metodologi yang digunakan pada tahun 2015 adalah analisis Computable General Equilibrium (CGE) dengan model GTAP (Global Trade Analysis Project) dan model gravity. Perbedaannya, penelitian ini menggunakan analisis Export Product Dynamic (EPD), Indeks Intra-Industry Trade (IIT), dan analisis Inter-Regional Input-Output (IRIO), serta pendekatan kualitatif dan kuantitatif untuk melihat potensi peningkatan akses pasar produk Indonesia ke FTAAP.

Sejauh pengetahuan kami, masih belum banyak penelitian yang mengkaji secara komprehensif terutama mengenai potensi peningkatan akses pasar produk Indonesia ke perekonomian APEC untuk mengantisipasi realisasi FTAAP dengan EPD, IIT dan IRIO. Ada kebaruan (novelty) dari penelitian ini yaitu sektor unggulan irisan dari perhitungan EPD, IIT dan IRIO bisa menjadi indikasi sektor yang dapat diminta/request kepada ekonomi mitra FTAAP apabila Indonesia bergabung dengan kerja sama ini. Dari penjelasan diatas, maka analisis ini bertujuan untuk melihat bagaimana Potensi Peningkatan Akses Pasar Produk Indonesia ke Perekonomian APEC untuk Mengantisipasi Realisasi FTAAP.

\section{METODE}

\section{Model Export Product Dynamic (EPD)}

Export Product Dynamic (EPD) merupakan metode analisis untuk mengidentifikasi produk atau komoditi atau sektor yang mempunyai daya saing yang tinggi serta pertumbuhan ekspor produk atau komoditi atau sektor yang cepat pada arus perdagangan suatu negara (Pradipta \& Firdaus, 2014; Kanaya \& Firdaus, 2014; Zuhdi \& Suharno; 2015). Terdapat beberapa faktor yang dipakai untuk mengidentifikasi cepatnya (dinamis) pertumbuhan ekspor suatu produk di suatu negara. Jika pertumbuhan ekspornya di atas rata-rata secara kontinyu selama waktu yang panjang, maka pertumbuhan ekspor produk ini dikatakan cepat dan produk ini mungkin menjadi sumber pendapatan ekspor yang penting bagi negara tersebut. Selanjutnya, jika produk dinamis 
tersebut mempunyai karakteristik produksi yang spesifik, maka hal ini juga menjadi informasi yang penting bagi kesempatan ekspor produk yang serupa. Adapun metode yang paling sering digunakan untuk mengidentifikasi produk-produk dinamis adalah dengan memilih produk-produk berdasarkan tingkat pertumbuhan pangsa pasar dan permintaan selama periode yang ditetapkan.

Matriks EPD terdiri dari daya tarik pasar dan informasi kekuatan bisnis. Daya tarik pasar dihitung berdasarkan pertumbuhan dari permintaan sebuah produk untuk tujuan pasar tertentu, di mana informasi kekuatan bisnis diukur berdasarkan pertumbuhan dari perolehan pasar (market share) sebuah negara pada tujuan pasar tertentu. Kombinasi dari daya tarik pasar dan kekuatan bisnis ini menghasilkan karakter posisi dari produk yang dianalisis ke dalam empat kategori yaitu Rising Star (RS), Lost Opportunity (LO), Falling Star (FS), dan Retreat (R). Rising Star adalah posisi ideal pada saat suatu komoditi/sektor telah naik atau tumbuh dengan pesat (fastgrowing products) dimana share of product meningkat dan share of country's export juga meningkat; Lost
Opportunity adalah posisi pada saat terjadi penurunan pangsa pasar suatu komoditi/sektor dimana share of country's export turun tetapi share of product meningkat; Falling Star adalah posisi pada saat share of country's export meningkat tetapi share of product menurun tetap meningkat; Retreat adalah posisi yang biasanya relatif tidak diinginkan, tetapi pada beberapa kasus tertentu 'mungkin' diinginkan jika pergerakannya menjauhi produk-produk yang stagnan dan menuju produkproduk yang dinamik (Bappenas, 2009 dan Nayantakaningtyas et al., 2017).

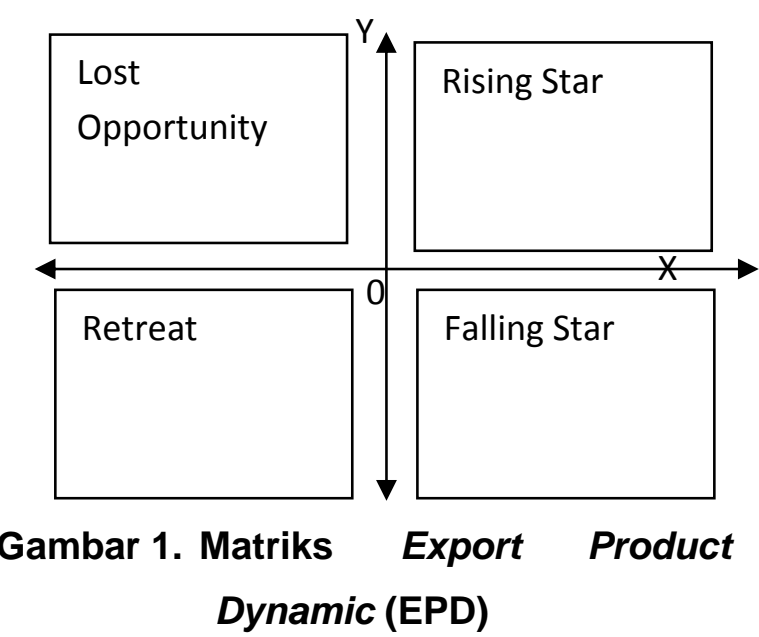

Sumber: Nabi \& Luthria (2002), Hasibuan, et al. (2012), Estherhuizen (2006) dan Bappenas (2009), diolah

Keterangan:

sumbu x: pertumbuhan pangsa ekspor suatu negara di pasar dunia

sumbu y: daya tarik pasar dari suatu komoditi / sektor 
Komoditi/sektor yang diestimasi posisi daya saingnya akan menempati salah satu dari empat kuadran (Gambar 1 dan Tabel 1), tergantung dari daya tarik pasar dan kekuatan bisnis komoditi/sektor tersebut. Dengan dimasukannya komoditi/sektor yang diuji ke dalam matriks EPD akan lebih mudah untuk melihat posisi daya saing masing-masing komoditi/sektor.

\section{Tabel 1. Kuadran Export Product Dynamic}

\begin{tabular}{lcc}
\hline \multirow{2}{*}{$\begin{array}{c}\text { Share of Country's } \\
\text { Export in World Trade }\end{array}$} & \multicolumn{2}{c}{$\begin{array}{c}\text { Share of Country's Product in } \\
\text { World Trade }\end{array}$} \\
\cline { 2 - 3 } & $\begin{array}{c}\text { Rising } \\
\text { (Dynamic) }\end{array}$ & $\begin{array}{c}\text { Falling } \\
\text { (Stagnant) }\end{array}$ \\
\hline Rising (Competitive) & Rissing Star & Falling Star \\
Falling (Non- & Lost & Retreat \\
Compeetitive) & Opportunity & \\
\hline
\end{tabular}

Sumber: Nabi \& Luthria (2002) dan Bappenas (2009) diolah

Adapun yang dimaksud dengan pangsa pasar ekspor suatu negara terhadap dunia (negara i) dan pangsa pasar produk (produk $n$ ) dalam perdagangan dunia adalah sebagai berikut:

Sumbu x: pertumbuhan pangsa pasar ekspor

$i=\frac{\sum_{t=1}^{t}\left(\frac{X_{\text {in }}}{X_{n}}\right)_{t} \times 100 \%-\sum_{t=1}^{t}\left(\frac{X_{\text {in }}}{X_{n}}\right)_{t-1} \times 100 \%}{T}$
Sumbu y: pertumbuhan pangsa pasar produk

$\mathrm{n}=\frac{\sum_{t=1}^{t}\left(\frac{X_{n}}{X}\right)_{t} \times 100 \%-\sum_{t=1}^{t}\left(\frac{X_{i n}}{X_{n}}\right)_{t-1} \times 100 \%}{T}$

Dimana:

$X$ : Volume Ekspor

$\mathrm{T}$ : Jumlah Tahun

$t:$ Tahun ke- $t$

\section{Model Intra-Industry Trade (IIT)}

Model Intra-Industry Trade (IIT) mencerminkan pertumbuhan intraregional blok perdagangan dan keuntungan yang dihasilkan dari perdagangan dengan meningkatkan variasi produk (Hamid \& Aslam, 2017). Intra-Industry Trade (IIT) index yang umum digunakan dengan rumus sebagai berikut (Bahari, 2015 dan IAMO, 2004):

$$
I I T=\left[1-\frac{\sum|X-M|}{\sum(X+M)}\right] x 100 \%
$$

Dimana : $\mathrm{X}=$ ekspor, $\mathrm{M}=$ impor. Jika jumlah yang diekspor sama dengan jumlah yang diimpor untuk suatu produk maka indeksnya bernilai 100\%, sebaliknya jika perdagangan suatu negara hanya melibatkan satu pihak saja (ekspor/impor saja) maka nilai indeksnya adalah nol. 
Data yang digunakan untuk menganalisis dengan IIT dan EPD berasal dari WITS periode tahun 20122015 dengan menggunakan HS tahun 2012. Komoditas yang dianalisis telah diklasifikasikan terlebih dahulu untuk menyesuaikan komoditas yang tersedia pada World Input-Output Database (WIOD) supaya nanti bisa dibandingkan dengan hasil penghitungan analisis dengan model IRIO.

\section{Model Inter-Regional Input-Output (IRIO)}

Tabel input-output disusun di tiap negara disusun olah National Statistics Agency (NSA) kalau di Indonesia disusun oleh badan statistik nasional. Data input-output Indonesia berasal dari Badan Pusat Statistik (BPS), terdiri dari matriks 180 dikali 180 input dan output industri, termasuk penggunaan permintaan akhir (final demand use). Analisis tabel input-output merupakan metode yang cocok untuk permasalahan ekonomi yang rumit karena dapat digunakan sebagai analisis lingkungan atau sosial yang menghasilkan studi dengan jangkauan yang luas (Sixta, 2017).

Aspek utama many-region InputOutput (Inter-Regional Input-Output/ IRIO) adalah mengukur dan memodelkan inter koneksi ekonomi antar region/wilayah (Gaftea, 2013). Dengan IRIO dapat diperoleh gambaran lebih detail impact multiplier, tidak hanya menurut sektor/produk namun juga berdasarkan wilayah. Tujuannya untuk mengidentifikasi current status akses pasar suatu produk dari suatu wilayah ke wilayah lain. Analisis input-output dapat mengidentifikasi linkages antara industri dengan sektor produksi dalam penggunaan bahan intermediate (Akhir et al., 2017).

Terdapat total 43 negara dan satu rest of the world yang ada didalam list negara dalam tabel Inter-Regional Input-Output (IRIO) yang dikeluarkan oleh lembaga OECD. Tabel IRIO ini didapat dari website www.wiod.org yaitu World Input-Output Database (WIOD). Inti data dari WIOD ini merupakan harmonisasi dari Supply and Use Tables (SUT) bersamaan dengan data perdagangan barang dan jasa internasional. Kedua kumpulan data ini terintegrasikan ke dalam kumpulan data tabel input-output antar negara (IRIO).

Dari total 21 ekonomi AsiaPasifik, ternyata baru ada 10 ekonomi yang tercantum dalam tabel IRIO. Meskipun demikian jumlah 10 ekonomi ini dianggap sudah mewakili dan 
mencukupi untuk melakukan penghitungan dengan menggunakan Analisis Inter-Regional Input-Output, diantaranya yaitu: (1) Australia (AUS), (2) Kanada (CAN), (3) RRT (CHN), (4) Indonesia (IDN), (5) Jepang (JPN), (6) Korea Selatan (KOR), (7) Mexico (MEX), (8) Russia (RUS), (9) Taiwan (TWN), dan (10) USA (USA).

\section{HASIL DAN PEMBAHASAN}

\section{Analisis EPD}

Analisis EPD bisa menghasilkan informasi mengenai posisi komoditi/ sektor di Indonesia dalam pasar internasional serta performance-nya (Nayantakaningtyas et al., 2017). Berdasarkan hasil analisis EPD dari 21 klasifikasi sektor yang telah dilakukan sebelumnya, sektor-sektor ekspor potensial Indonesia ke Pasar AsiaPasifik hanya berada pada posisi dua posisi, yaitu retreat dan falling star. Posisi falling star terdapat enam sektor, sisanya sebanyak 15 sektor berada pada posisi retreat (Tabel 2). Sebagian besar sektor ekspor utama Indonesia ternyata masih sangat kurang diminati pada pasar Asia-Pasifik yang ditunjukkan dengan masih lebih banyaknya sektor yang yang berada pada posisi retreat. Posisi ini menunjukkan bahwa baik pangsa pasar ekspor maupun pangsa pasar produk untuk 15 sektor sama-sama mengalami pertumbuhan yang negatif. Sektor yang berada pada posisi ini merupakan sektor yang sebenarnya dapat menjadi sektor unggulan Indonesia tidak hanya ke pasar Asia-Pasifik. Misalnya saja seperti sektor peternakan, perikanan, dan hasil hutan (kayu dan kertas). Peluang ekspor Indonesia seharusnya sangatlah besar mengingat luasnya dan banyaknya sektor-sektor tersebut dihasilkan di Indonesia. Padahal Indonesia adalah negara agraris dengan sektor pertanian, peternakan, perikanan sebagai sumber mata pencaharian mayoritas penduduk yang merupakan penyumbang devisa terbesar setelah sektor minyak dan gas (World Bank, 2003; Rompas, Engka \& Tolosang, 2015).

Selanjutnya, posisi enam sektor ekspor potensial Indonesia berada pada posisi falling star. Pada posisi ini, sebenarnya pertumbuhan pangsa pasar produk Indonesia di pasar Asia-Pasifik mengalami pertumbuhan yang negatif. Namun, pertumbuhan pangsa pasar ekspor secara keseluruhan di pasar Asia-Pasifik memiliki pertumbuhan yang positif. Hal ini dapat menjadi salah satu pemacu bagi Indonesia untuk dapat 
mengembangkan pasar produk untuk sektor pertambangan, industri makanan dan tembakau, industri pakaian, industri farmasi, industri produk non logam, serta industri kendaraan bermotor.
Apabila Indonesia dapat mengembangkan ekspor untuk sektor-sektor tersebut, maka peluang besar masih terbuka lebar bagi Indonesia untuk memasuki pasar Asia-Pasifik.

Tabel 2. Posisi Daya Saing Sektor Ekspor Potensial dan Utama Indonesia di Pasar Asia-Pasifik yang Perlu Dikembangkan

\begin{tabular}{|c|c|c|c|c|}
\hline No & Nama Sektor & Kode HS & $\begin{array}{c}\text { Pertumbuhan } \\
\text { Pangsa Pasar } \\
\text { Ekspor (\%) }\end{array}$ & $\begin{array}{l}\text { Posisi } \\
\text { Pasar }\end{array}$ \\
\hline 1 & produk tanaman dan hewan & $\begin{array}{l}\text { HS } 2012(01-21 \\
\text { except } 03)\end{array}$ & -2.05 & Retreat \\
\hline 2 & kehutanan dan penebangan kayu & HS $2012(44)$ & -0.51 & Retreat \\
\hline 3 & perikanan & HS $2012(03)$ & -6.48 & Retreat \\
\hline 4 & pertambangan dan penggalian & HS 2012 (25-26) & 35.95 & Falling star \\
\hline 5 & $\begin{array}{l}\text { industri produk makanan, } \\
\text { minuman dan tembakau }\end{array}$ & HS 2012 (22 and 24) & 2.61 & Falling star \\
\hline 6 & $\begin{array}{l}\text { industri tekstil, pakaian jadi dan } \\
\text { produk kulit }\end{array}$ & $\begin{array}{l}\text { HS } 2012(41-43 \text { and } \\
50-53)\end{array}$ & 3.59 & Falling star \\
\hline 7 & industri kayu & HS 2012 (45) & -15.06 & Retreat \\
\hline 8 & industri kertas & HS 2012 (46-49) & -0.96 & Retreat \\
\hline 9 & $\begin{array}{l}\text { pencetakan dan reproduksi } \\
\text { media rekaman }\end{array}$ & HS 2012 (37 and 90) & -17.61 & Retreat \\
\hline 10 & $\begin{array}{l}\text { industri coke dan minyak } \\
\text { sulingan }\end{array}$ & HS 2012 (27) & -12.95 & Retreat \\
\hline 11 & industri kimia & $\begin{array}{l}\text { HS } 2012(28,29,31- \\
36,38,84)\end{array}$ & -4.10 & Retreat \\
\hline 12 & industri farmasi & HS $2012(30)$ & 9.86 & Falling star \\
\hline 13 & industri karet dan plastik & HS 2012 (39-40) & -15.77 & Retreat \\
\hline 14 & $\begin{array}{l}\text { industri produk mineral non } \\
\text { logam }\end{array}$ & HS $2012(68,69,71)$ & 15.31 & Falling star \\
\hline 15 & industri logam dasar & HS 2012 (72-81) & -6.00 & Retreat \\
\hline 16 & industri produk logam fabricated & HS 2012 (82-83) & -12.37 & Retreat \\
\hline 17 & industri komputer dan elektronik & HS $2012(70)$ & -6.53 & Retreat \\
\hline 18 & industri peralatan listrik & HS 2012 (85) & -13.52 & Retreat \\
\hline 19 & $\begin{array}{l}\text { industri kendaraan bermotor, } \\
\text { trailer \& semi trailer }\end{array}$ & HS 2012 (87) & 0.89 & Falling star \\
\hline 20 & industri alat transportasi & HS $2012(86,88,89)$ & -19.58 & Retreat \\
\hline 21 & industri mebel & HS 2012 (94) & -8.28 & Retreat \\
\hline
\end{tabular}

Sumber : Hasil Perhitungan Peneliti 
Analisis Intra-Industry Trade (IIT)

Metode ini mengukur tingkat integrasi masing-masing sektor antara Indonesia dengan negara anggota yang tergabung dalam kawasan Asia-Pasifik. Tingkat integrasi diukur menggunakan aliran perdagangan yang dapat dilihat dari nilai ekspor dan impornya dari tahun 2012-2015. Semakin besar nilai integrasinya menunjukkan keterkaitan antar negara yang semakin erat. Salah satu kelemahan pengukuran tingkat integrasi model IIT dengan HS dua digit akan ada aggregation bias, namun karena keterbatasan data dan fungsi dari penghitungan model IIT ini untuk disinkronkan dengan penghitungan IRIO yang dalam tingkat agregat/sektoral maka harus dilakukan dalam HS dua digit. Penghitungan model IIT dengan HS dua digit juga sudah pernah dilakukan oleh beberapa peneliti sebelumnya seperti Bahari (2015) yang meneliti tentang IIT di sektor pertanian dan IAMO (2004) yang menulis tentang IIT di produk makanan negara Ukraina.

Tingkat integrasi tinggi menunjukkan adanya keterkaitan yang bersifat dua arah (two way trade) dimana Indonesia melakukan ekspor dan impor dengan negara dalam kawasan Asia-Pasifik. Hal ini juga dapat disebut sebagai aliran perdagangan yang bersifat intra industri. Sedangkan tingkat integrasi yang rendah menunjukkan adanya keterkaitan yang bersifat satu arah (one way trade) dimana Indonesia hanya melakukan ekspor atau impor saja dengan negara anggota dalam kawasan Asia-Pasifik. $\mathrm{Hal}$ in disebut juga sebagai aliran perdagangan yang bersifat interindustri.

Berdasarkan hasil analisis menggunakan IIT, sebanyak lima sektor ekspor Indonesia yang memiliki integrasi dalam kategori sangat kuat (Tabel 3). Artinya, sebanyak 23,81\% sektor ekspor Indonesia pada pasar Asia-Pasifik selama tahun 2012-2015 memiliki keterkaitan yang tinggi. Sektorsektor dengan integrasi sangat kuat diantaranya adalah hasil panen dan hewan, industri pengolahan makanan dan tembakau, industri farmasi, industri karet dan plastik, serta industri perakitan komputer.

Tidak terdapat sektor ekspor Indonesia ke pasar Asia-Pasifik yang masuk dalam kategori tidak ada integrasi. Hal ini menunjukkan bahwa antara Indonesia dengan kawasan AsiaPasifik telah memiliki hubungan 
perdagangan yang terbuka, hal ini sejalan dengan penelitian APEC (2009) yang menyatakan bahwa adanya bukti ilmiah ekonomi di APEC menjalani tingkat integrasi yang tinggi secara nyata. Sektor ekspor Indonesia yang masuk dalam kategori integrasi sedang dan kuat (Sharma, 1999) yaitu sebanyak 66,67\% dari total sektor yang dianalisis, dimana kategori integrasi ini berkisar antara 25,00-74,99. Sektor yang masuk dalam ketegori ini sebagian besar merupakan industri manufaktur.

\section{Tabel 3. Hasil Perhitungan Intra-Industry Trade untuk Sektor Ekspor Potensial dan Utama Indonesia di Pasar Asia-Pasifik}

\begin{tabular}{|c|c|c|c|c|c|c|}
\hline \multirow{2}{*}{ No } & \multirow{2}{*}{ Nama Sektor } & \multirow{2}{*}{ Kode HS } & \multicolumn{4}{|c|}{ Tahun } \\
\hline & & & 2012 & 2013 & 2014 & 2015 \\
\hline 1 & produk tanaman dan hewan & HS 2012 (01-21 except 03) & 88,13 & 95,17 & 92,85 & 84,26 \\
\hline 2 & kehutanan dan penebangan kayu & HS 2012 (44) & 26,61 & 24,01 & 20,62 & 19,82 \\
\hline 3 & perikanan & HS 2012 (03) & 12,89 & 12,49 & 10,90 & 11,51 \\
\hline 4 & pertambangan dan penggalian & HS 2012 (25-26) & 36,28 & 32,42 & 89,45 & 55,16 \\
\hline 5 & $\begin{array}{l}\text { industri produk makanan, } \\
\text { minuman dan tembakau }\end{array}$ & HS 2012 (22 and 24) & 98,24 & 93,11 & 85,28 & 78,03 \\
\hline 6 & $\begin{array}{l}\text { industri tekstil, pakaian jadi dan } \\
\text { produk kulit }\end{array}$ & $\begin{array}{l}\text { HS } 2012 \text { (41-43 and 50- } \\
53)\end{array}$ & 58,72 & 62,36 & 63,47 & 65,97 \\
\hline 7 & industri kayu & HS $2012(45)$ & 8,07 & 5,09 & 4,42 & 4,06 \\
\hline 8 & industri kertas & HS 2012 (46-49) & 65,29 & 67,49 & 74,97 & 69,25 \\
\hline 9 & $\begin{array}{l}\text { pencetakan dan reproduksi media } \\
\text { rekaman }\end{array}$ & HS 2012 (37 and 90) & 49,80 & 46,77 & 50,40 & 36,20 \\
\hline 10 & industri coke dan minyak sulingan & HS 2012 (27) & 68,40 & 74,96 & 79,07 & 75,24 \\
\hline 11 & industri kimia & $\begin{array}{l}\text { HS } 2012(28,29,31- \\
36,38,84)\end{array}$ & 46,61 & 50,18 & 53,55 & 48,25 \\
\hline 12 & industri farmasi & HS $2012(30)$ & 82,12 & 94,38 & 88,92 & 80,74 \\
\hline 13 & industri karet dan plastik & HS $2012(39-40)$ & 93,21 & 99,97 & 88,54 & 88,22 \\
\hline 14 & industri produk mineral non logam & HS $2012(68,69,71)$ & 48,57 & 40,22 & 35,19 & 57,04 \\
\hline 15 & industri logam dasar & HS 2012 (72-81) & 67,59 & 66,27 & 70,70 & 70,03 \\
\hline 16 & industri produk logam fabricated & HS 2012 (82-83) & 37,37 & 37,48 & 50,63 & 31,03 \\
\hline 17 & industri komputer dan elektronik & HS $2012(70)$ & 89,99 & 86,43 & 86,15 & 97,07 \\
\hline 18 & industri peralatan listrik & HS 2012 (85) & 68,07 & 67,61 & 66,37 & 64,82 \\
\hline 19 & $\begin{array}{l}\text { industri kendaraan bermotor, } \\
\text { trailer \& semi trailer }\end{array}$ & HS 2012 (87) & 57,00 & 57,98 & 75,23 & 85,05 \\
\hline 20 & industri alat transportasi & HS $2012(86,88,89)$ & 31,38 & 56,87 & 50,65 & 46,33 \\
\hline 21 & industri mebel & HS $2012(94)$ & 60,77 & 64,43 & 62,91 & 62,78 \\
\hline \multicolumn{3}{|c|}{ Share 5 Sektor terhadap 21 Sektor } & \multicolumn{4}{|c|}{$=(5 / 21) \times 100 \%=23,81 \%$} \\
\hline
\end{tabular}

Sumber : Hasil Perhitungan Peneliti 
Selanjutnya, terdapat dua sektor ekspor Indonesia yang masuk dalam kategori integrasi rendah, yaitu sektor dari sektor perkebunan dan kehutanan serta sektor perikanan. Sektor perkebunan dan kehutanan Indonesia hingga saat masih tergolong memiliki integrasi yang lemah dan terus menurun nilai indeksnya dikarenakan beberapa negara di kawasan Asia-Pasifik masih menerapkan tarif yang cukup tinggi untuk berbagai sektor hasil hutan dan perkebunan salah satunya produk kelapa sawit. Bahkan, banyak juga negara yang memperlakukan standar mutu yang sangat tinggi, sehingga ekspor Indonesia untuk jenis sektor tersebut sangat kecil karena banyaknya hambatan.

Selain itu, sektor perikanan Indonesia ternyata juga memiliki integrasi yang lemah terhadap negaranegara Asia-Pasifik. Sebagai negara kepulauan terbesar di dunia, Indonesia sebenarnya memiliki potensi sumber daya perikanan yang cukup tinggi. Berdasarkan data FAO (2010), Indonesia dengan total ekspor sebesar 5 juta ton per tahun merupakan salah satu penyumbang terbesar dalam produksi perikanan dunia di samping RRT dan Peru. Namun, yang masih menjadi kendala adalah sistem pendistribusian ikan tersebut. Kinerja logistik nasional secara umum masih belum menggembirakan. Hal ini terlihat dari Logistics Performance Index (LPI) yang dikeluarkan Bank Dunia dimana peringkat Indonesia menurun dari urutan 43 pada tahun 2007, menjadi urutan 75 pada tahun 2010 .

Selain itu, rendahnya integrasi perdagangan yang terjadi antara Indonesia dan negara di kawasan AsiaPasifik juga dikarenakan produk-produk perikanan Indonesia mengalami kalah saing jika dibandingkan dengan produk pangan lain (Rasyid, 2015). Permasalahan yang terjadi adalah usaha perikanan yang belum efisien maupun kontinuitas produksi yang tidak stabil. Penyebabnya antara lain adalah kurangnya sarana prasarana maupun pengetahuan untuk meningkatkan atau memberikan nilai tambah pada produk perikanan. Dampak dari rendahnya daya saing produk perikanan tangkap adalah berkurangnya lapangan pekerjaan, yang diiringi menurunnya pendapatan masyarakat. Secara global maka negara juga akan mengalami kerugian akibat menurunnya devisa.

Perdagangan Indonesia di pasar Asia-Pasifik selama tahun 2012 hingga 
tahun 2015 menunjukkan kinerja yang masih jauh dari harapan. Hal ini ditunjukkan melalui analisis EPD yang lebih banyak berada pada posisi retreat. Retreat yang menunjukkan adanya kinerja ekspor relatif stagnan atau bahkan turun (Nayantakaningtyas et al., 2017). Apabila disandingkan dengan analisis IIT menunjukkan bahwa sebenarnya antara Indonesia dengan Asia-Pasifik memiliki integrasi yang tergolong kuat. Hal ini dapat dijadikan peluang bagi Indonesia untuk terus meningkatkan ekspor ke pasar AsiaPasifik, terutama untuk sektor yang berada pada posisi falling star. Apabila Indonesia dapat memanfaatkan peluang ini, maka Indonesia dapat memaksimalkan manfaat dari pembentukaan Free Trade of the Agreement Asia-Pasific (FTAAP) pada masa yang akan datang. Pada sektor yang memiliki integrasi yang lemah, Indonesia juga dapat meningkatkan ekspornya dengan terus mengupayakan peningkatan daya saing dan nilai tambah (value added) produk agar dapat bersaing di pasar Asia-Pasifik.

Analisis Inter-Regional Input-Output (IRIO)

Adanya peningkatan jumlah metode analisis menggunakan Inter-
Regional Input-Output (IRIO) membuat lebih banyak peneliti menggunakan metode ini untuk analisis khusus di negara tertentu (Marconi et al., 2016; Okadera et al., 2014). Hal ini mengkonfirmasi pentingnya penggunaan analisis IRIO yang telah dikembangkan oleh Timmer et al. (2015). Peran utama dari model IRIO yaitu adanya penjelasan dari proses dekomposisi pengaruh nasional terhadap data tabel input-output regional dimana efek sektor-sektor tertentu di dalam suatu negara bisa berperilaku unik berdasarkan karakteristik masing-masing sektor (Šafr \& Vitavská, 2017). Jadi karakteristik sektor industri di suatu negara adalah unik dan penggunaan analisis IRIO bisa menangkap keunikan tersebut dengan melihat hubungan antar sektor dan antar negara yang berinteraksi dalam tabel input-output tersebut.

Dari 21 ekonomi Asia-Pasifik hanya 10 ekonomi Asia-Pasifik yang memiliki data perdagangan dalam Tabel World Input-Output Database (WIOD). Menurut (Xing, 2017), data Input-Output diadopsi untuk memodelkan network sektor industri yang kompleks sehingga bisa menganalisis secara detail rantai 
nilai global/Global Value Chains perdagangan dengan RRT, Jepang, (GVCs). Lebih lanjut Rodrigues et al. USA, Korea Selatan dan Taiwan (2016), menjelaskan bahwa model dengan persentase ekspor masingInput-Output juga dapat menjelaskan masing sebesar 11,61\%; 11,14\%; perdagangan antara sektor dan region 11,19\%; 4,85\%; dan 2,53\%; sedangkan yang berbeda secara luas yang dapat dipergunakan untuk melihat dampak lingkungan dari aktivitas ekonomi.

Berdasarkan data Trademap, persentase ekspor masing-masing sebesar 22,7\%; 9,57\%; 5,4\%; 4,92\% dan 2,13\%. Hal ini mengindikasikan bahwa Jepang, RRT, USA, Korea terlihat bahwa share perdagangan bilateral terbesar Indonesia diantara Selatan dan Taiwan merupakan mitra utama perdagangan Indonesia di Asiaekonomi Asia-Pasifik adalah Pasifik (Tabel 4).

Tabel 4. Share Perdagangan Indonesia dan Ekonomi Asia-Pasifik dibandingkan dengan Dunia

\begin{tabular}{cccc}
\hline No. & $\begin{array}{c}\text { Ekonomi } \\
\text { Asia-Pasifik }\end{array}$ & $\begin{array}{c}\text { Ekspor Indonesia ke Ekonomi } \\
\text { Asia-Pasifik dibandingkan } \\
\text { dengan Dunia }\end{array}$ & $\begin{array}{c}\text { Impor Indonesia dari Ekonomi } \\
\text { Asia-Pasifik dibandingkan } \\
\text { dengan Dunia }\end{array}$ \\
\hline 1 & RRT & 11,61 & 22,70 \\
2 & Jepang & 11,14 & 9,57 \\
3 & USA & 11,19 & 5,40 \\
4 & Korea Selatan & 4,85 & 4,92 \\
5 & Taiwan & 2,53 & 2,13 \\
6 & Australia & 2,21 & 2,09 \\
7 & Kanada & 0,51 & 1,02 \\
8 & Rusia & 0,87 & 0,63 \\
9 & Meksiko & 0,56 & 0,13 \\
\hline
\end{tabular}

Sumber: Trademap (2017), diolah

Berdasarkan Analisis Tabel InputOutput, terlihat bahwa ekspor Indonesia ke beberapa ekonomi di Asia-Pasifik seperti: Taiwan, RRT, Jepang, Australia, Rusia, Korea Selatan, dan Meksiko lebih banyak didominasi oleh produk-produk yang dapat dikategori- kan sebagai barang intermediate atau produk tersebut akan dipakai lagi sebagai input dalam industri. Sedangkan, ekspor Indonesia ke Amerika Serikat dan Kanada didominasi oleh produk final demand atau yang dikonsumsi langsung (Tabel 5). 
Tabel 5. Share Ekspor Indonesia ke Ekonomi Asia-Pasifik Sebagai Intermediate Input dan Final Demand

\begin{tabular}{clcc}
\hline No & Negara & $\begin{array}{c}\text { Share Ekspor sebagai } \\
\text { Intermediate Input }\end{array}$ & $\begin{array}{c}\text { Share Ekspor sebagai } \\
\text { Final Demand }\end{array}$ \\
\hline 1 & Taiwan & 92,26 & 7,74 \\
2 & RRT & 82,28 & 17,72 \\
3 & Jepang & 78,14 & 21,86 \\
4 & Australia & 70,68 & 29,32 \\
5 & Rusia & 63,50 & 36,50 \\
6 & Korea Selatan & 61,87 & 38,13 \\
7 & Meksiko & 60,46 & 39,54 \\
8 & Kanada & 48,26 & 51,74 \\
9 & USA & 37,29 & 62,71 \\
\hline
\end{tabular}

Sumber: Hasil Analisis

Terdapat 10 sektor dengan nilai ekspor terbesar untuk intermediate input dari Indonesia ke ekonomi yang nanti tergabung dalam FTAAP yaitu: (1) industri karet dan plastik; (2) industri logam dasar; (3) industri kimia; (4) industri tekstil, pakaian jadi dan produk kulit; (5) industri produk makanan, minuman dan tembakau; (6) industri kertas; (7) pertambangan dan penggalian; (8) industri coke dan minyak sulingan; (9) industri kayu; dan (10) produk tanaman dan hewan. Ke 10 sektor ini menjadi prioritas request untuk dimintakan penurunan hambatan baik tarif dan non-tarif (NTM) ke ekonomi yang nanti tergabung dalam FTAAP (Tabel 6).

Tabel 6. Sepuluh Sektor dengan Nilai Ekspor Terbesar untuk Intermediate Input dari Indonesia ke Ekonomi FTAAP

\begin{tabular}{|c|c|c|c|c|c|c|c|c|c|c|c|}
\hline No. & Sektor & Australia & Kanada & China & Jepang & Korea & Meksiko & Rusia & Taiwan & USA & Jumlah \\
\hline 1 & $\begin{array}{l}\text { industri karet } \\
\text { dan plastik }\end{array}$ & $\mathrm{V}$ & $\mathrm{V}$ & $\mathrm{V}$ & $\mathrm{V}$ & V & $\mathrm{V}$ & $\mathrm{V}$ & $\mathrm{V}$ & $\mathrm{V}$ & 9 \\
\hline 2 & $\begin{array}{l}\text { industri logam } \\
\text { dasar }\end{array}$ & V & - & V & V & V & V & V & V & V & 8 \\
\hline 3 & industri kimia & V & - & V & - & V & V & V & V & V & 7 \\
\hline 4 & $\begin{array}{l}\text { industri tekstil, } \\
\text { pakaian jadi } \\
\text { dan produk } \\
\text { kulit }\end{array}$ & V & V & - & V & V & V & V & V & - & 7 \\
\hline 5 & $\begin{array}{l}\text { industri produk } \\
\text { makanan, } \\
\text { minuman dan } \\
\text { tembakau }\end{array}$ & V & V & V & - & V & V & V & - & V & 7 \\
\hline
\end{tabular}




\begin{tabular}{|c|c|c|c|c|c|c|c|c|c|c|c|}
\hline No. & Sektor & Australia & Kanada & China & Jepang & Korea & Meksiko & Rusia & Taiwan & USA & Jumlah \\
\hline 6 & industri kertas & - & V & $\mathrm{V}$ & V & V & - & V & V & V & 7 \\
\hline 7 & $\begin{array}{l}\text { pertambangan } \\
\text { dan } \\
\text { penggalian }\end{array}$ & V & - & V & V & V & - & - & V & V & 6 \\
\hline 8 & $\begin{array}{l}\text { industri coke } \\
\text { dan minyak } \\
\text { sulingan }\end{array}$ & V & V & V & V & V & - & - & V & - & 6 \\
\hline 9 & industri kayu & V & V & V & V & V & - & - & V & & 6 \\
\hline 10 & $\begin{array}{l}\text { produk } \\
\text { tanaman dan } \\
\text { hewan }\end{array}$ & - & V & - & - & - & V & V & V & V & 5 \\
\hline
\end{tabular}

Sumber: Hasil Analisis

Adapun 10 sektor dengan nilai listrik; (9) industri coke dan minyak impor terbesar untuk intermediate input dari ekonomi yang nanti tergabung sulingan; dan (10) produk tanaman dan dalam FTAAP ke Indonesia yaitu: (1) hewan. Ke 10 sektor ini bisa menjadi industri kimia; (2) industri mesin dan peralatan; (3) industri logam dasar; (4) industri komputer dan elektronik; (5) prioritas indikasi offer dari Indonesia kepada ekonomi yang ingin tergabung dalam persiapan kemungindustri logam fabricated; (6) industri tekstil, pakaian jadi dan produk kulit; (7) kinan realisasi FTAAP untuk diturunkan tarifnya karena menjadi input untuk industri kertas; (8) industri peralatan industri Indonesia (Tabel 7).

Tabel 7. Sektor dengan Nilai Impor Terbesar untuk Intermediate Input dari Ekonomi FTAAP ke Indonesia

\begin{tabular}{|c|c|c|c|c|c|c|c|c|c|c|c|}
\hline No. & Sektor & Australia & Kanada & China & Jepang & Korea & Meksiko & Rusia & Taiwan & USA & Jumlah \\
\hline 1 & industri kimia & $\mathrm{V}$ & $\mathrm{V}$ & $\mathrm{V}$ & $\mathrm{V}$ & $\mathrm{V}$ & $\mathrm{V}$ & $\mathrm{V}$ & $\mathrm{V}$ & $\mathrm{V}$ & 9 \\
\hline 2 & $\begin{array}{l}\text { industri mesin } \\
\text { dan peralatan }\end{array}$ & - & V & V & V & V & V & V & V & V & 8 \\
\hline 3 & $\begin{array}{l}\text { industri logam } \\
\text { dasar }\end{array}$ & V & - & V & V & V & V & V & V & - & 7 \\
\hline 4 & $\begin{array}{l}\text { industri } \\
\text { komputer dan } \\
\text { elektronik }\end{array}$ & - & V & V & V & V & V & - & V & V & 7 \\
\hline 5 & $\begin{array}{l}\text { industri logam } \\
\text { fabricated }\end{array}$ & V & - & V & V & V & - & - & V & V & 6 \\
\hline 6 & $\begin{array}{l}\text { industri } \\
\text { tekstil, } \\
\text { pakaian jadi } \\
\text { dan produk } \\
\text { kulit }\end{array}$ & - & - & V & V & V & V & - & V & - & 5 \\
\hline
\end{tabular}




\begin{tabular}{|c|c|c|c|c|c|c|c|c|c|c|c|}
\hline No. & Sektor & Australia & Kanada & China & Jepang & Korea & Meksiko & Rusia & Taiwan & USA & Jumlah \\
\hline 7 & industri kertas & - & V & - & - & - & - & V & V & V & 4 \\
\hline 8 & $\begin{array}{l}\text { industri } \\
\text { peralatan } \\
\text { listrik }\end{array}$ & - & - & V & V & V & v & - & - & - & 4 \\
\hline 9 & $\begin{array}{l}\text { industri coke } \\
\text { dan minyak } \\
\text { sulingan }\end{array}$ & - & - & - & - & V & - & V & V & V & 4 \\
\hline 10 & $\begin{array}{l}\text { produk } \\
\text { tanaman dan } \\
\text { hewan }\end{array}$ & V & V & - & - & - & - & - & - & V & 3 \\
\hline
\end{tabular}

Sumber: Hasil Analisis

Untuk produk final product, 10 mebel; (5) industri peralatan listrik; (6) sektor dengan nilai ekspor terbesar dari Indonesia ke ekonomi yang nantinya tergabung dalam FTAAP yaitu: (1) industri komputer dan elektronik; (2) mesin dan peralatan; (7) industri karet dan plastik; (8) industri coke dan minyak sulingan; (9) industri kimia; serta (10) industri tekstil, pakaian jadi dan produk akomodasi dan pelayanan makanan. $\mathrm{Ke}$ 10 sektor ini bisa diprioritaskan untuk kulit; (3) industri produk makanan, dimintakan penurunan hambatan tarif minuman dan tembakau; (4) industri dan non-tarif (NTM) (Tabel 8).

Tabel 8. Sektor dengan Nilai Ekspor Terbesar untuk Final Product dari Indonesia ke Ekonomi FTAAP

\begin{tabular}{|c|c|c|c|c|c|c|c|c|c|c|c|}
\hline No. & Sektor & Australia & Kanada & China & Jepang & Korea & Meksiko & Rusia & Taiwan & USA & Jumlah \\
\hline 1 & $\begin{array}{l}\text { industri } \\
\text { komputer } \\
\text { dan } \\
\text { elektronik }\end{array}$ & $\mathrm{V}$ & $\mathrm{V}$ & $\mathrm{V}$ & $\mathrm{V}$ & $\mathrm{V}$ & $\mathrm{V}$ & $\mathrm{V}$ & $\mathrm{V}$ & $\mathrm{V}$ & 9 \\
\hline 2 & $\begin{array}{l}\text { industri } \\
\text { tekstil, } \\
\text { pakaian jadi } \\
\text { dan produk } \\
\text { kulit }\end{array}$ & v & v & v & v & v & v & v & v & v & 9 \\
\hline 3 & $\begin{array}{l}\text { industri } \\
\text { produk } \\
\text { makanan, } \\
\text { minuman } \\
\text { dan } \\
\text { tembakau }\end{array}$ & V & v & v & v & v & V & V & V & v & 9 \\
\hline 4 & $\begin{array}{l}\text { industri } \\
\text { mebel }\end{array}$ & V & V & V & V & V & V & V & V & V & 9 \\
\hline 5 & $\begin{array}{l}\text { industri } \\
\text { peralatan } \\
\text { listrik }\end{array}$ & - & - & v & v & v & v & v & v & v & 7 \\
\hline 6 & $\begin{array}{l}\text { industri } \\
\text { mesin dan } \\
\text { peralatan }\end{array}$ & v & v & - & v & v & v & v & - & - & 6 \\
\hline
\end{tabular}




\begin{tabular}{|c|c|c|c|c|c|c|c|c|c|c|c|}
\hline No. & Sektor & Australia & Kanada & China & Jepang & Korea & Meksiko & Rusia & Taiwan & USA & Jumlah \\
\hline 7 & $\begin{array}{l}\text { industri } \\
\text { karet dan } \\
\text { plastik }\end{array}$ & $\mathrm{V}$ & $\mathrm{V}$ & - & $\mathrm{V}$ & - & $\mathrm{V}$ & - & $\mathrm{V}$ & $\mathrm{V}$ & 6 \\
\hline 8 & $\begin{array}{l}\text { industri } \\
\text { coke dan } \\
\text { minyak } \\
\text { sulingan }\end{array}$ & V & - & V & V & V & - & - & V & - & 5 \\
\hline 9 & $\begin{array}{l}\text { industri } \\
\text { kimia }\end{array}$ & v & - & - & - & V & - & V & - & V & 4 \\
\hline 10 & $\begin{array}{l}\text { akomodasi } \\
\text { dan } \\
\text { pelayanan } \\
\text { makanan }\end{array}$ & V & V & - & V & - & - & - & - & - & 3 \\
\hline
\end{tabular}

Sumber: Hasil Analisis

Untuk produk final product, 10 sektor dengan nilai impor terbesar dari ekonomi yang nanti tergabung dalam FTAAP ke Indonesia yaitu: (1) industri produk makanan, minuman dan tembakau; (2) industri mesin dan peralatan; (3) industri kendaraan bermotor, trailer dan semi trailer; (4) industri komputer dan elektronik; (5) produk tanaman dan hewan; (6) industri peralatan listrik; (7) industri kimia; (8) industri karet dan plastik; transportasi udara; dan (10) produk gambar, video, televisi, suara dan musik. Ke 10 sektor ini harus dilihat lebih detail mana yang dapat diproduksi di Indonesia dan yang belum dapat. Sektor-sektor yang Indonesia sudah mampu memproduksi sendiri, dapat diprioritaskan untuk tidak ditawarkan/ offer dalam ekonomi yang akan tergabung dalam FTAAP (Tabel 9).

Tabel 9. Sektor dengan Nilai Impor Terbesar untuk Final Product dari Ekonomi FTAAP ke Indonesia

\begin{tabular}{|c|c|c|c|c|c|c|c|c|c|c|c|}
\hline No. & Sektor & Australia & Kanada & China & Jepang & Korea & Meksiko & Rusia & Taiwan & USA & Jumlah \\
\hline 1 & $\begin{array}{l}\text { industri } \\
\text { produk } \\
\text { makanan, } \\
\text { minuman } \\
\text { dan } \\
\text { tembakau }\end{array}$ & V & V & $\mathrm{V}$ & $\mathrm{V}$ & V & V & V & $\mathrm{v}$ & V & 9 \\
\hline 2 & $\begin{array}{l}\text { industri } \\
\text { mesin dan } \\
\text { peralatan }\end{array}$ & - & V & V & V & V & v & V & V & V & 8 \\
\hline 3 & $\begin{array}{l}\text { industri } \\
\text { kendaraan } \\
\text { bermotor, } \\
\text { trailer \& semi } \\
\text { trailer }\end{array}$ & v & v & - & v & v & v & v & - & v & 7 \\
\hline
\end{tabular}




\begin{tabular}{|c|c|c|c|c|c|c|c|c|c|c|c|}
\hline No. & Sektor & Australia & Kanada & China & Jepang & Korea & Meksiko & Rusia & Taiwan & USA & Jumlah \\
\hline 4 & $\begin{array}{l}\text { industri } \\
\text { komputer } \\
\text { dan } \\
\text { elektronik }\end{array}$ & - & $\mathrm{V}$ & $\mathrm{V}$ & $\mathrm{V}$ & $\mathrm{V}$ & $\mathrm{V}$ & $\mathrm{V}$ & $\mathrm{V}$ & - & 7 \\
\hline 5 & $\begin{array}{l}\text { produk } \\
\text { tanaman dan } \\
\text { hewan }\end{array}$ & V & V & V & - & - & V & V & - & V & 5 \\
\hline 6 & $\begin{array}{l}\text { industri } \\
\text { peralatan } \\
\text { listrik }\end{array}$ & - & v & V & v & v & - & - & V & - & 5 \\
\hline 7 & industri kimia & - & - & - & V & V & - & V & V & V & 5 \\
\hline 8 & $\begin{array}{l}\text { industri karet } \\
\text { dan plastik }\end{array}$ & - & - & V & V & - & v & - & v & - & 4 \\
\hline 9 & $\begin{array}{l}\text { transportasi } \\
\text { udara }\end{array}$ & - & - & - & v & V & - & V & - & V & 4 \\
\hline 10 & $\begin{array}{l}\text { produk } \\
\text { gambar, } \\
\text { video, } \\
\text { televisi, } \\
\text { suara, dan } \\
\text { musik }\end{array}$ & V & - & - & - & - & V & - & - & V & 3 \\
\hline
\end{tabular}

Sumber: Hasil Analisis

KESIMPULAN DAN REKOMENDASI

KEBIJAKAN

Peningkatan akses pasar produk Indonesia ke ekonomi mitra Free Trade Area of The Asia-Pacific (FTAAP) dapat dilakukan dengan cara melihat sektor mana yang memiliki potensi bagus untuk dikembangkan. Sektor unggulan Indonesia bisa dilihat dari irisan perhitungan dari tiga metodologi penelitian yaitu Export Product Dynamic (EPD), Intra-Industry Trade (IIT), dan Inter-Regional Input-Output (IRIO) analysis.

Berdasarkan hasil analisis Export Product Dynamic (EPD), dari 21 sektor ekspor potensial Indonesia ke pasar Asia-Pasifik, ekspor potensial tersebut berada pada posisi retreat dan falling star. Produk Indonesia yang berada pada posisi retreat ada 15 sektor yaitu: (1) produk tanaman dan hewan; (2) kehutanan dan penebangan kayu; (3) perikanan; (4) industri kayu; (5) industri kertas; (6) pencetakan dan reproduksi media rekaman; (7) industri coke dan minyak sulingan; (8) industri kimia; (9) industri karet dan produk plastik; (10) industri logam dasar; (11) industri produk logam fabricated; (12) industri komputer dan elektronik; (13) industri peralatan listrik; (14) industri alat transportasi; serta (15) industri mebel.

Produk Indonesia yang berada pada posisi falling star terdapat 6 sektor yaitu: (1) pertambangan dan 
penggalian; (2) industri produk makanan, minuman dan tembakau; (3) industri tekstil, pakaian jadi dan produk kulit; (4) industri farmasi; (5) industri produk mineral non logam; serta (6) industri kendaraan bermotor. Hal ini berarti Indonesia masih punya peluang untuk dapat mengembangkan pasar ekspor untuk enam sektor produk tersebut.

Berdasarkan hasil analisis menggunakan pendekatan IntraIndustry Trade (IIT) pada periode 20122015 terdapat 12 sektor yang nilai integrasi ke pasar Asia-Pasifik tinggi antara 60 sampai dengan 100 yaitu sektor: (1) industri komputer dan elektronik, (2) industri karet dan plastik, (3) industri kendaraan bermotor, trailer \& semi trailer, (4) produk tanaman dan hewan, (5) industri farmasi, (6) industri produk makanan, minuman dan tembakau, (7) industri coke dan minyak sulingan, (8) industri logam dasar, (9) industri kertas, (10) industri tekstil, pakaian jadi dan produk kulit, (11) industri peralatan listrik, dan (12) industri mebel. Sisanya sembilan sektor memiliki nilai tingkat integrasi rendah (di bawah 60) yaitu: (1) industri non-logam, (2) pertambangan, (3) industri kimia, (4) industri transportasi lainnya, (5) industri printing, (6) industri logam fabricated, (7) kehutanan, (8) perikanan, dan (9) industri kayu.

Berdasarkan Analisis IRIO, sektor ekspor Indonesia yang dapat diprioritaskan untuk dimintakan penurunan hambatan tarif dan non-tarif di pasar Asia-Pasifik baik intermediate input dan final product yaitu: (1) industri karet dan plastik; (2) industri logam dasar; (3) industri kimia; (4) industri tekstil, pakaian jadi dan produk kulit; (5) industri kertas; (6) industri komputer dan elektronik; (7) industri kimia; (8) industri produk makanan, minuman dan tembakau; (9) industri mebel; dan (10) industri peralatan listrik.

Jadi berdasarkan analisis EPD, IIT dan IRIO, ada irisan tiga sektor unggulan Indonesia yang memiliki potensi peningkatan akses pasar ke ekonomi mitra FTAAP yaitu: (1) industri produk makanan, minuman dan tembakau, (2) industri farmasi, dan (3) industri tekstil, pakaian jadi dan produk kulit. Ketiga sektor ini direkomendasikan untuk bisa menjadi fokus Indonesia supaya dibuka akses pasarnya ke AsiaPasifik dalam rangka FTAAP karena potensi ekspor dan keterkaitan antar industrinya tinggi. Asistensi dan bantuan teknis dapat diberikan kepada sektor- 
sektor ekspor unggulan diantaranya berupa fasilitasi perdagangan apabila sektor tersebut mendapat hambatan terkait kebijakan dan regulasi yang masih relatif tinggi di perekonomian APEC.

Kemudian, sektor impor Indonesia untuk intermediate input yang bisa ditawarkan/offer untuk penurunan tarif dalam FTAAP yaitu: (1) industri kimia; (2) industri mesin dan peralatan; (3) industri logam dasar; (4) industri komputer dan elektronik; (5) industri logam fabricated.

Lalu, sektor impor Indonesia untuk final product yang mungkin akan diminta oleh ekonomi FTAAP untuk diturunkan hambatannya baik tarif maupun nontarif yaitu: (1) industri komputer dan elektronik; (2) industri tekstil, pakaian jadi dan produk kulit; (3) industri produk makanan, minuman dan tembakau; (4) industri mebel; dan (5) industri peralatan listrik.

Berdasarkan analisis InterRegional Input-Output (IRIO) terhadap 10 ekonomi Asia-Pasifik terlihat bahwa share perdagangan bilateral terhadap total ekspor terbesar yaitu Indonesia terhadap RRT dan Jepang dengan persentase masing-masing sebesar $1,22 \%$. Hal ini mengindikasikan bahwa
RRT dan Jepang masih tetap dua ekonomi yang memiliki posisi penting dalam kerja sama perdagangan di AsiaPasifik, sedangkan share perdagangan bilateral terhadap total ekspor terbesar yaitu terjadi dari Korea Selatan dan Taiwan terhadap Indonesia dengan persentase masing-masing sebesar 0,4\% dan 0,32\%. Adapun ekspor Indonesia ke Australia, RRT, Jepang, Korea Selatan, Meksiko, Rusia dan Taiwan didominasi oleh kategori barang intermediate dan ekspor Indonesia ke Amerika Serikat dan Kanada didominasi oleh kategori konsumsi langsung. Pada akhirnya diperlukan upaya peningkatan daya saing yang bisa dilakukan dengan transfer teknologi terutama dari perekonomian APEC yang lebih banyak impor intermediate-nya daripada produk finalnya. Kemudian peningkatan akses pasar agar lebih difokuskan pada final demand sehingga value added bisa didapat oleh Indonesia.

\section{UCAPAN TERIMA KASIH}

Pada kesempatan ini penulis ingin mengucapkan terima kasih kepada Kepala Badan Pengkajian dan Pengembangan Perdagangan, Sekretaris Badan Pengkajian dan Pengembangan Perdagangan, Kepala Pusat Pengkajian Kerja sama 
Perdagangan Internasional, Kepala

Bidang Regional, serta tim peneliti di Pusat Pengkajian Kerja sama Perdagangan Internasional. Selain itu penulis juga mengucapkan terima kasih kepada tenaga ahli yaitu Ibu Nur Indah Kristiani, S.Si, M.S.E dan Ibu Sri Retno Wahyu Nugraheni, S.E., M.Si. Ucapan terima kasih juga kepada mitra kerja Kementerian Perdagangan yang telah memberikan bantuan berupa ketersedian data dan informasi yang tidak bisa disebutkan satu persatu.

\section{DAFTAR PUSTAKA}

Akhir, N.H.M., Ismail, N.W., Kaliappan, S.R., Said, R. (2017). Intersectoral Linkages of Malaysian Batik Industry: An Application of Input-Output Analysis. Jurnal Ekonomi Malaysia 51(1) 2017, 55-66.

APEC. (2009). Trade Creation in the APEC Region: Measurement of the Magnitude of and Changes in Intraregional Trade since APEC's Inception. Research Paper APEC Policy Support Unit (Asia-Pacific Economic Cooperation PSU).

APEC. (2016). Collective Strategic Study on Issues Related to the Realization of the FTAAP. Report paper, APEC (Asia-Pacific Economic Cooperation), November 2016.

Bahari, Fitri. (2015). Analisis Perdagangan Intra Industri di Sektor Pertanian. Skripsi Program Sarjana Fakultas Ekonomi dan Bisnis Universitas Diponegoro.

Bappenas. (2009). Trade and Investment in Indonesia: a Note on Competitiveness and Future Challenge. Report Paper, Directorate of Trade, Investment and International Economic Cooperation,
Ministry of States for National Development Planning/ The National Development Planning Agency (Bappenas).

Bergsten, C. F. (2007). Toward a Free Trade Area of the Asia-Pacific. Working Paper, Policy Briefs in International Economics Number PB07-0, USA.

DJPEN. (2016). FTAAP, Jalan Menuju Pengintegrasian Ekonomi Asia Pasifik. Warta Ekspor, Direktorat Jenderal Pengembangan Ekspor Nasional. Kementerian Perdagangan.Jakarta.

Estherhuizen, D. (2006). Measuring and Analyzing Competitiveness in the Agribusiness Sector: Methodological and Analytical Framework. University of Pretoria.

FAO. (2010). The State of World Fisheries and Aquaculture 2010. Office of Knowledge Exchange, Research and Extension Food and Agriculture Organization of the United Nations.

Gaftea, V. (2013). The Input-Output Modeling Approach to The National Economy. Romanian Journal of Economic Forecasting, 2/2013, pp 211-222, University Tomis.

Hamid, M. F. S., \& Aslam, M. (2017). Intraregional Trade Effects of ASEAN Free Trade Area in the Textile and Clothing Industry. Journal of Economic Integration (JEI) Vol.32, No.3, September 2017, 660-688.

Hasibuan, A.M., Nurmalina, R., \& Wahyudi, A. (2012). Analisis Kinerja dan Daya Saing Perdagangan Biji Kakao dan Produk Kakao Olahan Indonesia di Pasar Internasional. Buletin Ristri Vol 3 (1) 2012.

IAMO. (2004). Intra-Industry Trade in Agricultural and Food Products: The Case of Ukraine. Discussion Paper No.78 2004 of Institut Fur 
Agrarentwicklung in Mittel-Und Osteuropa (IAMO)

Kanaya, I, A. Firdaus, M. (2014). Daya Saing Permintaan Ekspor Produk Biofarmaka Indonesia Di Negara Tujuan Utama Periode 20032012. Jurnal Manajemen \& Agribisnis, Vol.11 (3), pp.184198.

Marconi, N, I.L. Rocha, G.R. Magacho. (2016). Sectoral Capabilities and Productive Structure: An InputOutput Analysis of The Key Sectors of The Brazilian Economy. Brazilian Journal of Political Economy, Vol.36 (143), pp.470-492.

Nayantakaningtyas, J.S, A. Daryanto, I.T. Saptono.

(2017).

Competitiveness of Indonesian Tea In International Market. Indonesian Journal of Business and Entrepreneurship, Vol.3 (5), pp.14-23.

Nabi, I. \& Luthria, M. (2002). Building Competitive Firms: Incentives and Capabilities. The World Bank, Washington, D.C.

Okadera, T., Okamoto, N., Watanabe, M., Chontanawat, J. (2014). Regional water footprints of the Yangtze river: an interregional InputOutput Approach. Economic Systems Research, Vol. 26, No. 4, 2014, pp. 444-462.

Pradipta, A., Firdaus, M. (2014). Posisi Daya Saing dan Faktor-faktor yang Memengaruhi Ekspor Buahbuahan Indonesia. Jurnal Manajemen \& Agribisnis, Vol. 11, No.2, Juli 2014.

Puska KPI. (2015). Analisis Cost and Benefit Asia-Pacific Free Trade Agreement (FTA-AP). Laporan Akhir Penelitian Pusat Kebijakan Kerjasama Perdagangan Internasional, Kementerian Perdagangan.

Rasyid, Mohtar. (2015). Potensi Ekonomi Ikan dan Produk Perikanan Indonesia dalam Lingkup Masyarakat Ekonomi ASEAN. Prosiding Seminar Nasional Multidisiplin IImu dan Call for Papers UNISBANK (Sendi_U).

Rodrigues, J., Marques, A., Wood, R., and Tukker, A. (2016). A Network Approach for Assembling and Linking Input-Output Models. Economic Systems Research, 28:4, 518-538, DOI:

10.1080/09535314.2016.1238817.

Rompas, J., Engka, D., Tolosang, K. (2015). Potensi Sektor Pertanian dan Pengaruhnya Terhadap Penyerapan Tenaga Kerja di Kabupaten Minahasa Selatan. Jurnal Berkala IImiah Efisiensi, Volume 15 No.04 Tahun 2015.

Šafr, K., Vitavská, K. (2017). Illustration of Single-Regional and Inter-Regional Approach in Regional Input-Output Analysis. Statistika, 2017, 97(1).

Sharma, Kishor. (1999). Pattern and Determinants of Intra-Industry Trade in Australian Manufacturing. Center Discussion Paper No.813, Economic Growth Center Yale University.

Sixta, Jaroslav. (2017). Input-Output Approach to Regional Employment. Statistika, 2017, 97(1).

Timmer. M.P., Dietzenbacher, E., Los, B. Stehrer, R., Vries, G.J. (2015). An Illustrated User Guide to the World Input-Output Database: the Case of Global Automotive Production. Review of Internasional Economics, Volume 23, Issue 3, August 2015, Pages 575-705.

Trademap. (2017). Trade Statistics for Internasional Business Development. Research Database, Trademap. https://trademap.org/Index.aspx didownload 22 Desember 2017.

World Bank. (2003). Prioritas Masalah Pertanian di Indonesia. Agriculture Sector Review Indonesia, August 
2013, Carana Corporation for USAID and World Bank.

WTO. (2015). RTA Database. Research Database, World Trade Organization (WTO).

http://www.wto.org/english/tratop_e/r egion_e/region_e.htm didownload 13 Januari 2015.

Xing, L. (2017). Analysis of inter-country input-output table based on citation network: How to measure the competition and collaboration between industrial sectors on the global value chain. PloS ONE 12(9): e018405.

Zuhdi, Fadhlan \& Suharno. (2015). Analisis Daya Saing Ekspor Kopi Indonesia dan Vietnam di Pasar ASEAN 5. Habitat, Volume 26, No.3, Desember 2015, Hal. 152-162. 
